\title{
Study the effect of Trigonella Foenum-Graecum Foenugreek on some parameters of sperm and serum in Alloxan diabetic mice
}

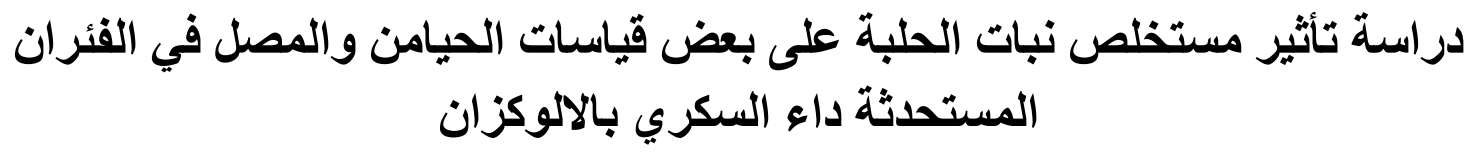

Hazim I. Al-Ahmed

Biotechnology Research Center/ Al-Nahrain University

\section{Abstract}

The influence of fenugreek injected (IP) on male fertility by using following tests (measurement of testosterone level, sperm viability, activity, motility and abnormalities) and on GOT, GPT, Al.ph. and Lipid profile status was studied in normal and alloxan diabetic mice. Alloxan diabetic mice were injected with Trigonella extract for 5 weeks at a dosage of $2 \mathrm{~g} / \mathrm{kg}$ body weight. The Alloxan diabetic mice exhibited enhanced decrease significantly in glucose level in serum. Increased testosterone level and decreased dead sperms, abnormalities and increase motility, decrease in GOT, GPT, AL.PH. and lipid profile, in alloxan diabetic mice.

المستخلص

دراسة تأثير حقن مستخلص نبات الحلبة (بالبخلب البريتوني) على خصوبة ذكور الفئران من خلال قياس ( مستوى هرمسون التيستوسـتيرون فـي مصـل الــلم ، فعاليـة الحيـامن ، تثــوهات الحيـامن) وقيـاس مسـتوى انـزيم ال GOT,GPT , AL.PH. تم حقن الفئران المستحثثة السكري بمستخلص نبات الحلبة لمدة 5 اسابيع وبجرعة 2 غم/كفم من وزن الجسم ، وقد لوحظ انخفاض مستوى الكلوكوز في مصل الدم في الفئران المستحثثة السكري ، وارتفاع مستوى هرمون التستوستيرون في مصل الدم وقلة عدد الحيامن الميتة والتشوهات ، وزيادة فعالية الحيامن ، كما لوحظ انخفاض مستوى الانزيمات .GOT, GPT, Al.ph وتحليل الدهون في الفئران المستحثثة السكري بأستخدام الالوكزان . 


\section{Introduction:}

Trigonella fraenum graecum (fenugreek)

is traditionally used to treat disorders such as diabetes, high cholesterol, wounds, inflammation, and gastrointestinal ailments [17].

Recent studies suggest that fenugreek and its active constituents may possess anticariogenic potential $[15,20]$.

Trigonella seeds and some of its fraction have a hypoglycaemic effect in experimentally induced diabetes $[17,21]$ and have hypercholesterolemic activity in rats $[10,12]$. Fenugreek has very important roles to improve fertility due to it contain diogesine that considered

\section{Materials and methods}

Plant materials: Fenugreek seeds were purchased from the local market and identified in a Biotechnology Research Centre-Al-Nahrain University. The seeds were cleaned and finely powdered, the powder was mixed with normal saline $(1 \% \mathrm{w} / \mathrm{v})$ and injected the mice (IP) at level $2 \mathrm{~g} / \mathrm{kg}$ body weight.

Animal care: Healthy adult albino males of Swiss albino strain were obtained from animal house of Biotechnology Research Center- Al-Nahrain University. 35 mice were used in this study, the age of the mice were in the range of 2.5 to 3 precursor for synthesis of sex hormone [22].

Fenugreek display hypoglycaemic and hypo cholesterol acmic effects and are considered tope potentially useful for glucose control and in the treatment of hyperlipidemia and a atherosclerosis in diabetic subjects [20].

The present study, determined the effect of fenugreek in normal and alloxandiabetic mice on male fertility (sperm viability and abnormalities), GOT, GPT, alkaline phosphatase and on lipid profile (cholesterol,

HDL-cholesterol, Triglyceride).

months old, and the weight in the range 25-30 grams. The animals were housed in small plastic cages, which were cleaned weekly by washing with soap and tap water and sterilized with $70 \%$ ethyl alcohol throughout the period of the study. The room temperature was maintained at $(24 \pm 2)^{\circ} \mathrm{C}$, and the animals were exposed to 14 hours light program. Induction of Diabetes: Diabetes was induced by a single intraperitoneal injection of alloxan monohydrated (5\% $\mathrm{w} / \mathrm{v}$ ) in physiological saline at a dose of $150 \mathrm{mg} / \mathrm{kg}$ body weight in a volume of 
$0.1 \mathrm{ml}$. The diabetic state was confirmed 48 hours after alloxan injection by weight loss [5], and hyperglycaemia [18]. There was $75 \%$ mortality in animals treated with alloxan. Surviving mice with a fasting blood glucose level higher than $200 \mathrm{ml} / \mathrm{dl}$ were included in the study. Seven groups consisting of five animals for each group were maintained as follows:

Experimental group

Control group: Normal mice injected with $0.1 \mathrm{ml}$ of physiological saline.

Group A:-Normal mice injected with alloxan $0.1 \mathrm{ml}$ to formed diabetic mice.

Group B:-Diabetic mice treated with $0.1 \mathrm{ml}$ of Trigonella extract after one week from treated with alloxan.

Group C:- 2 week

Group D:- 3 week

Group E:- 4 week

Group F:- 5 week

General procedure:- Blood sugar levels were determined periodically by heart puncture at the end of $(1,2,3,4$ and 5 weeks) from treated with alloxan, the mice fasted over night and killed by cervical dislocation.

Treatments of male: - The testes were removed and placed in a sterile disposable Petri dish containing $1 \mathrm{ml}$
TCM-199 medium, then the epididymes were isolated and spermatozoa were obtained from the two tails of epididymes by mixing in $1 \mathrm{ml}$ TCM-199, and maintained at $37^{\circ} \mathrm{C}$ in $5 \% \quad \mathrm{CO}_{2}$ incubator prior treatments.

Microscopically

examination:-

Spermatozoa were assessed according to WHO Laboratory manual for viability, activity, Motility and abnormalities.

Testosterone assay:- Bio merieux Italia S.P. a vidia campigliano, 58 50015-point A EMA $\left(\mathrm{F}_{1}\right)$ Italia miniVIDAS. Was used for the hormonal assay.

C. Bio merieux Sa.69230 marcy I'Etoile

- France, testo sterone for 30 sample (test), code No. 09345B. In testosterone test the assay principle combines an enzyme immuno assay sandwich method with a final fluorescent detection (ELFA).

Biochemical measurements:-

1. GOT, GPT.-

According to [16], blood was collected from the mice by heart puncture .The serum was separated by centrifugation at $2000 \mathrm{rpm}$ for $10 \mathrm{~min}$. Then, the serum was taken and treated as follows:

Two test tubes were used for each sample, the $1^{\text {st }}$ one contained the blank reagent and $2^{\text {nd }}$ contains the sample. 
These samples were treated as in the following:-

\begin{tabular}{|l|c|c|}
\hline & GPT & GOT \\
\hline Reagent 1 & $1 \mathrm{ml}$ & - \\
Reagent 2 & - & $1 \mathrm{ml}$ \\
\hline
\end{tabular}

Incubate for $5 \mathrm{~min}$ at $37^{\circ} \mathrm{C}$.

\begin{tabular}{|l|c|c|}
\hline Serum & $0.2 \mathrm{ml}$ & $0.2 \mathrm{ml}$ \\
\hline $\begin{array}{l}\text { Mix and incubate at } \\
37^{\circ} \mathrm{C}\end{array}$ & - & - \\
\hline Reagent 3 & $1 \mathrm{ml} \mathrm{min}$. \\
\hline $\begin{array}{l}\text { Mix. Let stand for } \\
20 \mathrm{~min} \text { at room temp }\end{array}$ & $10 \mathrm{ml}$ & $1 \mathrm{ml}$ \\
\hline \begin{tabular}{l}
$\mathrm{NaOH} \mathrm{0.4} \mathrm{N}$ \\
\hline
\end{tabular}
\end{tabular}

Mixed wait 5 min. measure under condition identical to those used for the standard curve.

Wavelength: $505 \mathrm{~nm}(490$ - 520nm)

Activities of these two enzymes in the serum were estimated from the activity table attached with kit of each enzyme.

3. ALP(alkaline phosphates)

Sample used in this test was the same of serum sample used for GPT\& GOT tests.
To estimate the activity of the ALP enzymes, procedure of [11] was used: four test tubes for each sample were prepared, the $1^{\text {st }}$ one contain the sample, the $2^{\text {nd }}$ is the blank sample, the $3^{\text {rd }}$ contain the standard sample and the $4^{\text {th }}$ is the blank reagent, as shown below:- 


\begin{tabular}{|c|c|c|c|c|}
\hline & $\begin{array}{l}\text { Serum } \\
\text { sample }\end{array}$ & $\begin{array}{l}\text { Serum } \\
\text { bank }\end{array}$ & Standard & $\begin{array}{l}\text { Reagent } \\
\text { blank }\end{array}$ \\
\hline Reagent & $2 \mathrm{ml}$ & $2 \mathrm{ml}$ & $2 \mathrm{ml}$ & $2 \mathrm{ml}$ \\
\hline \multicolumn{5}{|c|}{ Incubate for 5 minutes at $37^{\circ} \mathrm{C}$. } \\
\hline Serum & $50 \mu 1$ & - & - & - \\
\hline Reagent 2 & - & - & $50 \mu 1$ & - \\
\hline \multicolumn{5}{|c|}{ Incubate for exactly $15 \mathrm{~min}$ at $37^{\circ} \mathrm{C}$. } \\
\hline Reagent 3 & $0.5 \mathrm{ml}$ & $0.5 \mathrm{ml}$ & $0.5 \mathrm{ml}$ & $0.5 \mathrm{ml}$ \\
\hline \multicolumn{5}{|c|}{ Mixed well or preferably vortex. } \\
\hline Reagent 4 & $0.5 \mathrm{ml}$ & $0.5 \mathrm{ml}$ & $0.5 \mathrm{ml}$ & $0.5 \mathrm{ml}$ \\
\hline Serum & - & $50 \mu 1$ & - & 一 \\
\hline Distilled water & - & - & - & $50 \mu 1$ \\
\hline \multicolumn{5}{|c|}{ Mix. Let stand for 10 minutes in the dark. } \\
\hline Measure. & & & & \\
\hline
\end{tabular}

Calculation $=$

$$
\text { OD serum sample } \quad-\quad \text { OD serum blank }
$$

OD standard

\section{Lipid profile}

Determination of Serum Total

Cholesterol in the serum was measured by enzymatic method, with the biomerux kit.

\section{Principle}

The principle of this method was lysis of the cholesterol ester to produce cholesterol and fatty acids, then oxidized to produce the quinoemine:

$$
\text { cholesterol ester } \stackrel{\text { cholesterol esterase }}{\longrightarrow} \text { cholesterol + fatty acid }
$$$$
\text { cholesterol } \stackrel{\text { cholesterol oxidase }}{\longrightarrow} \text { cholest }-4-\text { en }-3 \text {-one }+\mathrm{H}_{2} \mathrm{O}_{2}
$$

$2 \mathrm{H}_{2} \mathrm{O}_{2}+$ phenol $+4-$ amino antipyrine $\stackrel{\text { peroxidase }}{\longrightarrow}$ quinoe $\min e+4 \mathrm{H}_{2} \mathrm{O}_{2}$ 


\section{Reagents:}

The reagent used in test is a mixture of:

1- phosphate buffer

$0.1 \mathrm{~mol} / \mathrm{L}$

2- phenol
4- 4 samino antipyrine

5- peroxidase

6- cholesterol oxidase

7- cholesterol esterase
$0.5 \mathrm{mmol} / \mathrm{L}$

$\geq 1000 \mathrm{u} / \mathrm{L}$

$\geq 200 \mathrm{u} / \mathrm{L}$

$\geq 125 \mathrm{u} / \mathrm{L}$

3- sodium cholate surfaetante $\quad 3.74$

$\mathrm{mmol} / \mathrm{L}$

Procedure:

The procedure for this method is as follow:

\begin{tabular}{|l|c|c|c|}
\cline { 2 - 4 } \multicolumn{1}{c|}{} & Reagent blank & Standard & Sample \\
\hline Standard $200 \mathbf{m g} / \mathbf{d L}$ & - & $10 \mu \mathrm{L}$ & - \\
\hline Sample & - & - & $10 \mu \mathrm{L}$ \\
\hline Working reagent & $1 \mathrm{ml}$ & $1 \mathrm{ml}$ & $1 \mathrm{ml}$ \\
\hline
\end{tabular}

After addition, mixing the content of absorbance by spectrophotometer at 500 every tube. Allow staying at room temperature for 10 minutes or incubating at $37^{\circ} \mathrm{C}$ for 5 minuts and reading $\mathrm{nm}$. The intensity of the produces color is directly proportional to total cholesterol concentration in the sample.

Total cholesterol $(\mathrm{mmol} / \mathrm{L})=\frac{\text { Abs. of sample }}{\text { Abs. of standard }} \times 5.17$

Determination of Serum Triglyceride

Total triglycerides in the serum were measured by enzymatic with the (biomerieux kit.)
Principle

Total triglyceride determination depend on formation of quinonemine by using a group of enzymes as follows:

\footnotetext{
Triglycerides $\stackrel{\text { lipase }}{\longrightarrow}$ glycerol + fatty acids

Glycerol + ATP $\stackrel{\text { glyverokinase }}{\longrightarrow}$ glycerol $-3-$ phosphate $+A D P$

glycerol -3-phsphate $\stackrel{\text { glycerol-3-phosphate }}{\longrightarrow} \mathrm{H}_{2} \mathrm{O}_{2}+$ dihydroxy-acetone phosphate

$\mathrm{H}_{2} \mathrm{O}_{2}+$ parachlorophenol + amino antipyrine $\stackrel{\text { peroxidase }}{\longrightarrow}$ quinonei mine $+\mathrm{H}_{2} \mathrm{O}_{2}+\mathrm{HCL}$
} 


\section{Reagents:}

The reagent used in this test is a mixture of:

1- Buffer $\mathrm{pH} 7.6$ $100 \mathrm{mmol} / \mathrm{L}$

2- $\mathrm{p}$ - Cholesterol

3- Magnesium $2.7 \mathrm{mmol} / \mathrm{L}$ $4 \mathrm{mmol} / \mathrm{L}$

4- 4- Aminoantipyrine $\quad 0.4 \mathrm{mmol} / \mathrm{L}$
5- Lipase

$\geq 1000 \mathrm{u} / \mathrm{L}$

6- Glycerokinase

$\geq 200 \mathrm{u} / \mathrm{L}$

7- Glycerol - 3- phosphate oxidase

Procedure: $\geq 2000 \mathrm{u} / \mathrm{L}$

8- Peroxidase

$\geq 200 \mathrm{u} / \mathrm{L}$

9- ATP

$0.8 \mathrm{mmol} / \mathrm{L}$

10- Glycerol

\begin{tabular}{|l|c|c|c|}
\cline { 2 - 4 } \multicolumn{1}{c|}{} & Reagent blank & Standard & Sample \\
\hline Standard $200 \mathbf{~ m g} / \mathbf{d l}$ & - & $10 \mu \mathrm{L}$ & - \\
\hline Sample & - & - & $10 \mu \mathrm{L}$ \\
\hline Working reagent & $1 \mathrm{ml}$ & $1 \mathrm{ml}$ & $1 \mathrm{ml}$ \\
\hline
\end{tabular}

Gently mix the content of every tube spectrophotometrically at $505 \mathrm{~nm}$. The after addition, allow staying at $20-25^{\circ} \mathrm{C}$ intensity of the produced color is temperature for 10 minute or incubating at $37^{\circ} \mathrm{C}$ for 5 minutes and reading proportional to total triglyceride in the sample.

Calculation:

Sample concentration $=\stackrel{\text { Abs. of sample }}{\times} \mathrm{n}(\mathrm{n}=$ concentration of standard $\mathrm{n}=2.29)$ Abs. of standard

Determination of Serum High Density Lipoprotein - Cholesterol (HDL - C):

HDL - Cholesterol the serum were measured by enzymatic method using biomeriex kit,.

2.6.3.2 Reagents:

\begin{tabular}{|c|c|c|}
\hline \multirow{3}{*}{$\begin{array}{ll}\text { HDL } \quad- & \text { cholesterol } \\
\text { precipitant } & \end{array}$} & Phosphotungstic acid & $40 \mathrm{~g} / \mathrm{L}$ \\
\hline & $\mathrm{MgCl}_{2} .6 \mathrm{H}_{2} \mathrm{O}$ & $100 \mathrm{~g} / \mathrm{L}$ \\
\hline & pH 6.2 & $1 \mathrm{~g} / \mathrm{L}$ \\
\hline
\end{tabular}


Procedure:

\begin{tabular}{|l|c|c|c|}
\cline { 2 - 4 } \multicolumn{1}{c|}{} & Reagent blank & Standard & Sample \\
\hline Distilled water & $50 \mu \mathrm{L}$ & - & - \\
\hline HDL - calibrator & - & $50 \mu \mathrm{L}$ & - \\
\hline Supernatant & - & - & $1 \mathrm{ml}$ \\
\hline Working reagent & $1 \mathrm{ml}$ & $1 \mathrm{ml}$ & - \\
\hline
\end{tabular}

The working solution is the cholesterol incubate it for 5 minutes at $37^{\circ} \mathrm{C}$ and enzymatic solution gently mix with the then read spectrophotometrically at 500 contents of every tube; after the addition nm.

let it stay at $20-25$ for 10 minutes or

Calculation:

HDL. Cho. $(\mathrm{mmol} / \mathrm{L})=\underline{\text { Abs of sample }} \times 1.42$

Abs. of standard

$(1.42=$ the concentration of standard $)$

*Statistical analysis

Statistical analysis was performed to compare two different groups by using ANOVAtest. Statistical significance was determined at $\mathrm{P}<0.05 \cdot[1]$.

\section{Results and discussions:-}

The glucose level increased in serum of normal mice from that indicated to induced alloxan-diabetic mice as reported by[4].Table (1).

Alloxan diabetic mice treated with Trigonella were shown reduced glucose level in serum from $181.32 \pm 1.60$ to 274.0+2.04 Table(1).They also conclude that fenugreek seeds improve insulin sensitivity and decrease insulin resistance in diabetic mice [8]. The hypoglycaemia effects have been attributed to several mechanisms [7].The amino acid 4-hydroxyisoleucine in fenugreek seeds increased glucoseinduced insulin release in pancreatic islet cells [19]. This amino acid appeared to act only on pancreatic beta cells, fenugreek reduced the area under the plasma glucose curve and increased the number of insulin receptors [14].

In humans, fenugreek seeds exert hypoglycaemia effect by stimulating glucose-dependent insulin secretion 
from pancreatic beta cells [2] as well as by inhabiting the activities of alphaamylase and sucrose to intestinal enzymes involved in carbohydrate metabolism [3].

The results obtained increased body weight in alloxan diabetic mice treated with the fenugreek extract Table( 2). The increased in body weight due to the fenugreek extract contain materials have very important roles in metabolism such as amino acids and alkaloids [24].

While the increased testes weight due to fenugreek extract contain coumarin which cause accumulation of water in testes. Table( 2).

Testosterone level no significant decrease in alloxine male diabetic mice to compared with control male $(1.63 \pm 0.03,1.66 \pm 0.91)$ respectively. Foenugreek extract also increased the testosterone level $(2.97 \pm 0.03)$ after 5 weeks from treated. This increased due to that the fenugreek contain diosgenin which have important roles in sex hormone synthesis. [6, 23]. Table( 3).

The results obtained no significant decrease in viability, dead spermatozoa, abnormalities $(60 \pm 3.23,34 \pm 1.91$ and $25+2.20)$ respectively in alloxan diabetic male mice to compared with control male $\quad(75 \pm 2.66, \quad 32 \pm 0.92$ and $22 \pm 1.61)$ respectively. While fenugreek extract increased Table (4).

The increase fertility of spermatozoa due to increase the level of testosterone in serum $[6,23]$.

Table 5 showed increased in triglyceride total cholesterol and HDL-cholesterol $203.40+0.78,242.31 \pm 1.34$ and 218.80 \pm 1.72 in alloxan-diabetic mice $166.40 \pm 2.70 \quad, \quad 201.30 \pm 1.61$ and $170.33+2.50$ respectively to compared with control 169.51 $\pm 3.41,204.10 \pm 2.91$ and $\quad 176.31 \pm 3.02 \quad$ respectively. Feungreek seeds also lower cerium TG, chol. and HDL-Chol. 237.3 \pm 141 , $87.77 \pm 3.01$ and $90.60 \pm 4.51$ respectively after 5 weeks. These effects may be due to saponins ,alkaloids, or to the high fibber content of the seeds.[7,9].This study have ability of fenugreek to significantly reduced of GOT, GPT, Al.ph., in alloxan mice from $196.22 \pm 2.11 \quad, \quad 68.77 \pm 1.94 \quad$ and $66.42 \pm 0.91$ respectively to $203.41 \pm 69.12 \pm 191$ and $68.31 \pm 1.61$ respectively after 5 weeks from treated with fenugreek seeds. Table(6) The method of action is unknown but may be due to the saponine, alkaloids, or to the high fibre content of the seeds.[13] 


\section{References}

1. Al-Mohammed, N.T.; Al-Rawi, K.M.; Younis, M.A. and Al-Morani, W.K. (1986). Principle of Statistics. J. AlMousl University (in Arabic).

2. Ajabnoor, MA.and Tilmisany AK. (1998). Effect of Trigonella foenum graceum on blood glucose levels in normal and alloxan-diabetic mice. J., Ethnopharmacol. 22: 45-49.

3. Amin, R; Abdul-Ghani AS.; Suleiman MS. (1987). Effect of Trigonella foenum graceum on intestinal absorption. Proc. of the $47^{\text {th }}$ Annual Meeting of the American Diabetes Association (Indiana Polis U.S.A.). 36: $211 \mathrm{a}$.

4. Anuradha, CV. and Ravikumar, P. (2001). Restoration on tissue antioxidants by fenugreek seeds (Trigonella foenum graecum) in alloxandiabetic rats. Indian J. Physiol. Pharmacol. 45(4): 408-420.

5. Benedict SR. 1911 The detection and estimation of glucose in urine. J. Am. Med. Assoc.: 57: 1193-1196.

6. Dean, W. 2004. What Influences Testosterone Levels. J. of Endurance.7: 2-7.

7. Ethan Basch, MD; Catherine Ulbricht, Pharm D.; Grace Kuo, Pharm D.; Philippe Szapory, MD; Michael Smith,
MR Pharms, ND. (2003). Therapeutic Applications of fenugreek. Alternative Medicine Review, Volume 8, No.1 (2027).

8. Gupta, A.; Gupta, R.; Lal, B. (2002). Effect of Trigonella foenum-graceum (fenugreek) seeds on glycaemic control and insulin resistance in type $\mathrm{z}$ diabetes mellitus: a double blind placebo controlled study. The Journal of the Association of Physicicans of India. 49: (1057-1061).

9. Hebel SK eds (1997). Fenugreek, in the Lawrence Review of Natural Products. St. Louis: Facts and comparisons, 1996: 1-3.

10. Khosal, P.; Gupta, D.D. and Nagpul, P.K. (1995). Effect of Trigonella foenum (fenugreek) on serum lipids in normal and diabetic rats. Indian J. Pharmacol. 27: 89-93.

11. Kind, P.R., \& King, E.G. (1945): Clin. Path., 7:322.

12. Madar Z. And Odes, H.S. (1990). Dietary fibre in metabolic disease in Dietary fibre Research, ed. By R. Paoletti, pp. 1-54. Karger, Base 1.

13. Nakhla, HB.; Mohammed OS.; Abu IM.; Fatuh AL.; Adam SE $>$ (1991). The effect of Trigonella foenum graecum 
(fenugreek) crude safonins on Hisextype Chicks. Vet. Hum. Toxical. 33(6): 561-4.

14. Raghuram T.C.; Sharma R.D.; Sivakumar, P. (1994). Effect of foenugreek seeds on intravenous glucose disposition in non-insulin dependent diabetic patients. Phytother Res. 8: 8386.

15. Raju，J.; Patlolla JM; Swamy MV, Raocv. Diosgenin, asteroid saponin of Trigonella foenum graceum (fenugreek) inhibits azoxymethane-induced abberant crypt foci formation in F344 rats and induces opoptosis in HT-29 human colon cancer cells. Cancer Epidemiolo Biomarkers Prev. 2004, Aug: 13(8): 1392-8.

16. Reittman, S., \&Frankel, S. (1957): Amer. J. Clin. Path., 28:56

17. Ribes, G.; Sauvaire, Y.; Da Costa, C.; Baccou, J.C. and Loubatiers-Mariani, M.M. (1986). Anti-diabetic effects of subfractions from fenugreek seeds in diabetic dogs. Proc. Soc. Exp. Biol. Med. 182, 159-166.

18. Sasaki T.; matsui S.. Effect of acetic acid concentration on the colour reaction in the O-toluidine boric acid method for the blood glucose determination. Rinsho Kagaku, 1972; 1: 346-353.
19. Sauvairey Y., Petit, P.; Broca C. (1998). 4-Hydroxisoleucine: a novel amino acid Potentiator of Insulin secretion. Diabetes. 47: 206-210.

20. Sharma R.D.; Sherker A.; Hazra DK; Hypolipidaemic effect of fenugreek seeds; achromic study in non insulin defendent diabetic patients. Phytother Res. 1996: 10, 332-334.

21. Shani J.; Goldschemied, A; Ahroson, Z. And Sulman, F.G.,(1974). Hypocholestrolaemic effect of Trigonella foenum greacum and Lupins Termis (Leguminosac) seeds and their major alkaloid in alloxan diabetic and normal rats. Arch. Int $>$ Pharmacodyn. Ther., 210, 27-36.

22. Taylor, W.G. Zulyniak, H.J.; Richard, KW.; Acharya,Sn.; Bittman ,Sand Elder,JL.(2002).Variation in Diosgenin levels among 10 Accessions of fenugreek seeds in western Canada. J. Agric. And Food. Chemis. 50 (21).Pp. 5994-5997.

23. Vora, P. 2000. What every Man should know about Andropause. Natural Health $\&$ Beauty Care Center. 8 PP. San June Capistrano.

24. Zubay, G.; Parson, W. \& Vance, D.1995. Principles of Biochemistry. 50-66 PP. Brown publishers. England. 